\title{
Benignus multicysticus peritonealis mesothelioma
}

\author{
György Alpár dr. ${ }^{1}$ - Schmal Ferenc dr. ${ }^{1}$ - Szabó Huba dr. ${ }^{2}$ \\ Tóth Lajos Barna dr. ${ }^{3}$ - Lukovich Péter dr. ${ }^{1}$
}

\author{
${ }^{1}$ Szent János Kórház, Sebészeti Osztály, Budapest \\ ${ }^{2}$ Szent János Kórház, Patológiai Osztály, Budapest \\ ${ }^{3}$ Jósa András Oktatókórház, Sebészeti Osztály, Nyíregyháza
}

\begin{abstract}
A benignus multicysticus peritonealis mesothelioma a hashártyából kiinduló ritka, jóindulatú daganat, mely leginkább fiatal, reproduktív életkorban lévő nőket érint. A betegség klinikai képe teljesen aspecifikus, a pontos diagnózis emiatt nagyon sok esetben a végleges szövettani lelet segítségével kerül felállításra. A fiatal nőbeteg kizáródott lágyéksérv gyanújával, sürgősséggel került mútétre. A mútét során a Nuck-csatornában a ligamentum rotundummal összetapadó cystosus képlet került eltávolításra, ugyanakkor sérv nem volt észlelhetô. A szövettani vizsgálat benignus multicysticus peritonealis mesotheliomát igazolt. A beteget hyperthermiás intraperitonealis kemoterápiát végző osztályra irányítottuk, ahol laparoszkópos exploráció történt. Ennek során residualis tumor vagy egyéb eltérés nem volt észlelhető. Egy 41 éves férfi beteg 4 évvel a jelenlegi osztályos felvételt megelőzően köldöksérv miatt elektív mưtéten esett át. Ekkor a hasfali peritoneumról egy $2 \mathrm{~cm}$-es cysticus képletet exstirpáltak, melynek szövettana benignus multicysticus peritonealis mesotheliomát igazolt. 2018 márciusában periappendicularis abscessus gyanúja miatt történt mútétekor az appendix distalis részén, az appendixszel együtt, egy diónyi, többrekeszes cystosus képlet is eltávolításra került. A szövettan a primer tumor recidíváját igazolta. Kontroll radiológiai vizsgálat során nem volt residualis tumormasszára utaló eltérés. A benignus multicysticus peritonealis mesothelioma malignizálódásra való hajlama alacsony. En bloc mútéti eltávolítása javasolt, ebben az esetben a recidíva valószínűsége $50 \%$ körüli. Amennyiben az utánkövetés alatt a tumor kiújul, mérlegelendő a totális peritonectomia, illetve a hyperthermiás intraperitonealis kemoterápia elvégzése.
\end{abstract}

Orv Hetil. 2019; 160(21): 839-843.

Kulcsszavak: benignus multicysticus peritonealis mesothelioma, differenciáldiagnózis, hashártya, hyperthermiás intraperitonealis kemoterápia

\section{Benign multicystic peritoneal mesothelioma}

Benign multicystic peritoneal mesothelioma is a rare benign tumor originating from the peritoneum, affecting mostly young, fertile women. Its presentation is non-specific, thus the final diagnosis is made after the histological examination. A young female patient presented with incarcerated inguinal hernia of which an emergency surgery was performed. During the operation a cystic mass neighboring the round ligament in the canal of Nuck was removed. No inguinal hernia was found. The histological examination confirmed the diagnosis of benign multicystic mesothelioma. The patient was referred to a center performing hyperthermic intraperitoneal chemotherapy, where laparoscopic exploration was performed. The second surgery revealed no residual tumor or any other pathology. A 41-yearold male patient, 4 years before presenting at our ward, had an elective umbilical hernia repair surgery. During the operation $2 \mathrm{~cm}$ big cystic mass was removed from the peritoneum, and the histological examination revealed benign multicystic mesothelioma. In 2018, acute surgery was performed due to a periappendicular abscess, while during the surgery a multicystic mass situated on the distal end of the appendix was also removed. The pathological finding confirmed the recurrence of the first tumor. The radiological examination did not find any signs of residual tumor mass anywhere else. The chances of malignant transformation in cases of benign multicystic peritoneal mesothelioma are low. The suggested treatment is en bloc surgical removal of the mass, however, in these cases recurrence is still $50 \%$. If during follow-ups the recurrence of the tumor is found, a total peritonectomy or hyperthermic intraperitoneal chemotherapy is advisable. 
Keywords: benign multicystic peritoneal mesothelioma, differential diagnosis, peritoneum, hyperthermic intraperitoneal chemotherapy

György A, Schmal F, Szabó H, Tóth LB, Lukovich P. [Benign multicystic peritoneal mesothelioma]. Orv Hetil. 2019; 160(21): 839-843.

(Beérkezett: 2019. január 2.; elfogadva: 2019. január 27.)

\section{Rövidítések}

BMPM = (benign multicystic peritoneal mesothelioma) benignus multicysticus peritonealis mesothelioma; $\mathrm{CT}=$ (computed tomography) számítógépes tomográfia; $\mathrm{FNAB}=$ (fine needle aspiration biopsy) finomtü-aspirációs biopszia; HIPEC = (hyperthermic intraperitoneal chemotherapy) hyperthermiás intraperitonealis kemoterápia; $\mathrm{MRI}=$ (magnetic resonance imaging) mágnesesrezonancia-képalkotás

A BMPM ritka, jóindulatú daganat, amely a hashártya mesothelialis és mesenchymalis elemeiból származik [1]. Bár hisztológiai szempontból jóindulatú, és csak néhány esetben írták le malignus átalakulását, recidívahajlama, növekedése miatt klinikailag semimalignus tumor. A szakirodalomban ez idáig kevesebb mint 200 eset került leírásra [1]. A megbetegedés leginkább a nőket érinti, de néha férfiaknál is előfordul. A recidíva valószínüsége $50 \%$ körül van [2].

A BMPM ritka előfordulása, tünetmentessége és aspecifikus megjelenése miatt mütét előtt a legtöbbször nem sikerül a pontos diagnózis felállítása [2]. A leggyakrabban egyéb okból végzett hasi mütét vagy más okból készített képalkotó vizsgálat során kerül felismerésre a betegség. Panaszok esetén a betegek többsége krónikus vagy időszakos alhasi, illetve kismedencei fájdalmat említ [3]. Más esetekben fizikális vizsgálat során a has valamely területén tapintható hasi rezisztencia kivizsgálását követôen derül fény BMPM-ra [4]. Ezek mellett már leírásra került ileust okozó BMPM is $[1,5]$.

\section{Esetismertetések}

\section{Elsö beteg}

A 30 éves nőbeteg anamnézisében 6 hónapos korban strangulatiós ileus miatt végzett hasi mútét szerepelt. A páciens 5 évet dolgozott pékségben, magas hőmérsékleti körülmények között. Munkahelyén felmerült az azbesztexpozíció lehetősége, de ez irányban pontos adatok nem állnak rendelkezésünkre.

A beteget bal oldali kizáródott lágyéksérv iránydiagnózissal küldték sebészeti szakambulanciánkra. A páciensnek nem volt tudomása hasfali sérvről, panaszai 3 nappal korábban kezdődtek: kezdetben a bal lágyéktájon fájdalmatlan „dudort” észlelt, amely később erősen fájdalmassá vált. A fizikális vizsgálat során a bal lágyéktáji régióban egy kb. cseresznyényi nagyságú, tapintásra fájdalmas, irreponábilis terime volt észlelhető. A has más területe nem volt nyomásérzékeny, egyéb kóros rezisztencia nem volt tapintható. A laborleletben gyulladásra utaló jel vagy más eltérés nem volt. A hasi ultrahangvizsgálat a bal lágyéktáji régióban egy $3 \mathrm{~cm}$-es, folyadékkal telt terimét írt le, ezért kizárt bal oldali lágyéksérv iránydiagnózissal sürgôs mütétre került sor. Bal oldali inguinalis ferde metszést követően, a fascia meghasítása és a ligamentum rotundum izolálása után, a ligamentumon elhelyezkedő cseresznyényi nagyságú cystosus képletet exstirpáltuk. Ezt követően a hasfalat Bassini szerint zártuk.

A posztoperatív szak eseménytelen volt, a beteg szövődménymentesen gyógyult. A kórszövettani vizsgálat BMPM-t (multilocularis peritonealis inclusiós cysta) igazolt. A tumormarkerek (CEA, CA 19-9) a normális értékhatárokon belül voltak. Staging céljából mellkasi és hasi-kismedencei CT-vizsgálat történt, amely a mútéti területen residualis tumormasszára utaló jelet nem mutatott ki. A máj 8-as szegmentumában egy 1,5 cm nagyságú terimét írtak le, mely a radiológiai kép alapján nagy valószínúséggel focalis nodularis hyperplasiának felel meg. FNAB-vizsgálat nem történt a tumor elhelyezkedése, illetve az ebből adódó magas vérzési kockázat miatt. Mivel a BMPM kezelésére szóba jön a HIPEC-terápia, a beteget ennek elvégzésére alkalmas sebészeti centrumba irányítottuk, ahol laparoszkópos exploráció történt. Ennek során residualis tumort nem találtak, HIPEC-kezelésre és totális peritonectomiára nem volt szükség. 3 hónap múlva ismételten laparoszkópos exploráció történt, melynek során recidívára utaló jel nem volt észlelhető.

\section{Második beteg}

A 41 éves férfi beteg anamnézisében 4 éve - más intézetben - köldöksérv miatt elektív hasfali rekonstrukciós mütét szerepelt. A mütét során a hasfali peritoneumon egy $2 \times 2 \mathrm{~cm}$-es cystosus képlet került felfedezésre, majd ezt követően eltávolításra. A szövettani lelet BMPM-t igazolt. Mütétet követően egyéb érdemi vizsgálatra vagy további kezelésre nem került sor. A beteg 2018. március 23-án, 3 napja tartó jobb alhasi fájdalmak miatt került sebészeti osztályunkra felvételre. A laborleletekben enyhén emelkedett gyulladásos paraméterek voltak észlelhetők. A hasi ultrahangvizsgálat a periappendicularis abs- 


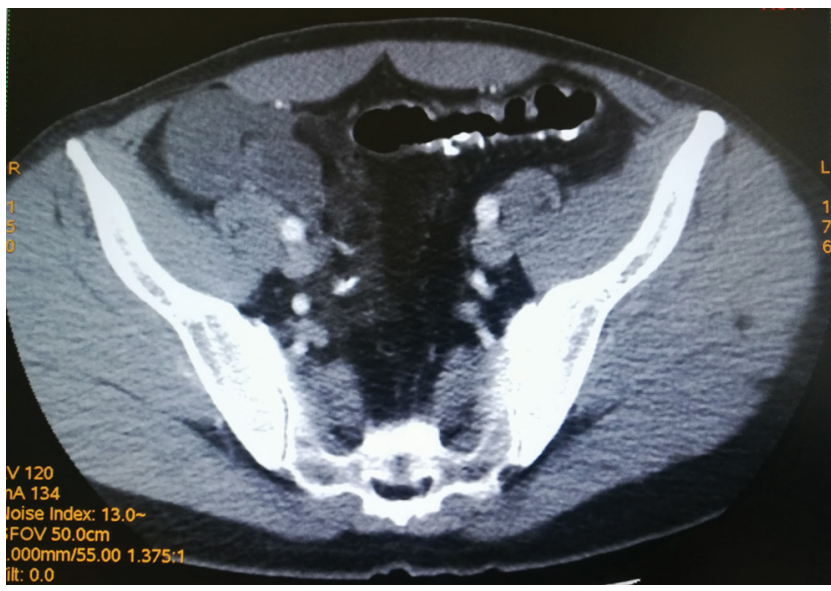

1. ábra

$$
\begin{aligned}
& \text { Az esetbemutatásban szereplő } 2 \text {. beteg preoperatív hasi CT-ké- } \\
& \text { pe, amelyen a coecum csúcsától a hólyagig húzódó, szabályta- } \\
& \text { lan, de körülhatárolt, rekeszes jellegú, sűrú folyadékdenzitású, } \\
& 80 \times 40 \times 40 \text { mm-es képlet észlelhető } \\
& \text { CT = számítógépes tomográfia }
\end{aligned}
$$

cessus lehetőségét vetette fel. Az elváltozás eredetének tisztázása érdekében hasi CT-vizsgálatra került sor, mely a coecum csúcsától kezdődő, valószínúleg azzal összefüggő, lefelé és medial felé, a hólyagig húzódó, szabálytalan, de körülhatárolt, rekeszes jellegú, sưrû folyadékdenzitású, $80 \times 40 \times 40$ mm-es képletet írt le (1.ábra).

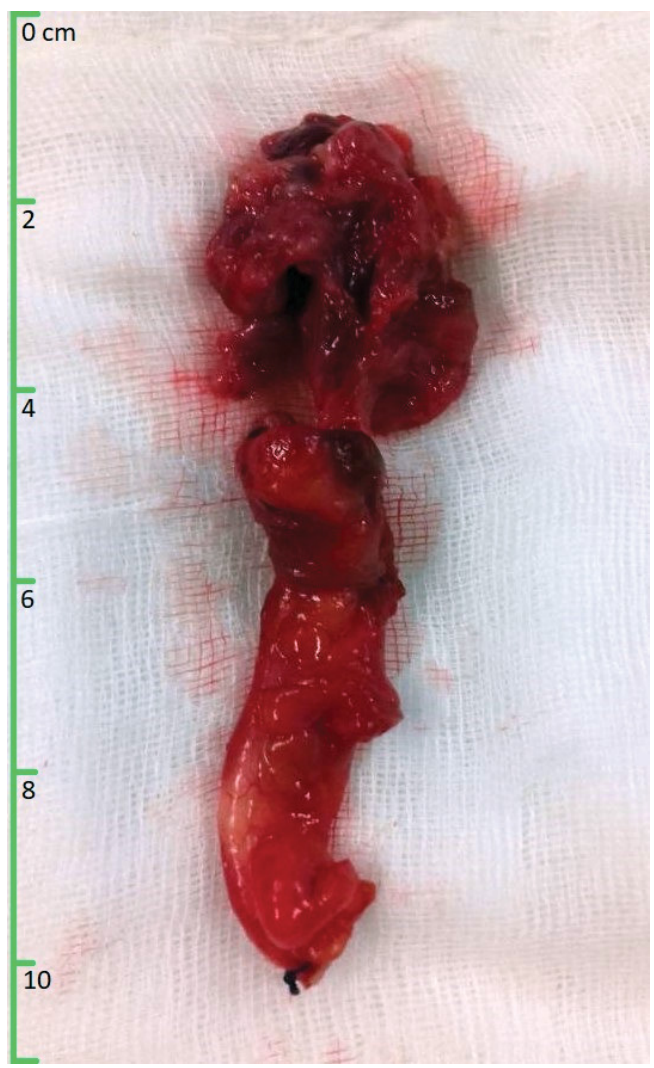

2. ábra

Reszekciót követően a kép alsó részén a gyulladt appendix, az appendix distalis végén cystosus, részben bevérzett BMPM

$\mathrm{BMPM}=$ benignus multicysticus peritonealis mesothelioma

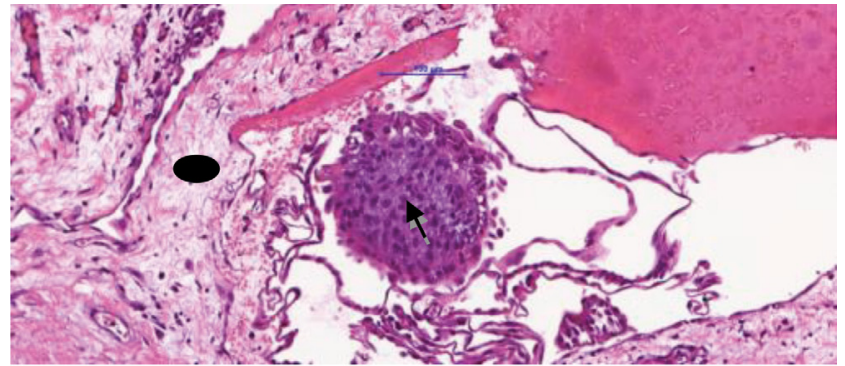

3. ábra

A BMPM szövettani képe. Hematoxilin-eozin festés, 300×-os nagyítás

$\mathrm{BMPM}=$ benignus multicysticus peritonealis mesothelioma

7 Típusos mesothelialis sejtekkel bélelt, változó tágasságú cysticus képletek, centrálisan reaktív mesothelialis proliferációval

A cysták között laza, ödémás kötőszövetes állomány látható

Periappendicularis folyadékgyülem, illetve tályog lehetősége merült fel, ezért hasi explorációt végeztünk. A mútét során a phlegmonosusan gyulladt appendix distalis végén egy $4 \times 3 \mathrm{~cm}$-es cystosus elváltozást találtunk. Egyértelmúen nem volt megállapítható, hogy a terime az appendix végéből vagy a mesoappendixból ered-e (2. ábra). Az appendix, illetve az elváltozás a mesoappendix ellátása után eltávolításra került. A posztoperatív szak eseménytelenül zajlott. A kórszövettani lelet alapján az appendix és az elváltozás közvetlen kötőszövetes öszszefüggésben volt egymással. A cystában a kifejezett akut lobsejtes beszưrődés mellett sarjszövetes átalakulás is láthatóvá vált, szövettanilag a képlet BMPM-nak felelt meg (3. ábra).

Mivel a BMPM recidívájáról volt szó, a beteget onkológiai központba irányítottuk, ahol hasi és kismedencei MRI-vizsgálat történt. Ez residualis tumort nem igazolt. További kontrollvizsgálatra, illetve egyéb kezelésre nem került sor.

\section{Megbeszélés}

A BMPM-t 1928-ban Plautírta le először [1]. Leiomyoma mütéti eltávolítása során a kismedencében több cystosus képletet észlelt, melyeket exstirpált. A specimen mesotheliomás eredetét azonban csak az elektronmikroszkóp bevezetését követően sikerült bizonyítani [3].

A BMPM etiopatogenetikai tényezői egyelőre még nem tisztázottak. A kis esetszám alapján elmondható, hogy a daganat gyakrabban alakul ki olyan betegeknél, akiknek anamnézisében már szerepelt hasi mútét [6], vagy egyéb hasi vagy kismedencei krónikus gyulladásos folyamaton estek át $[6,7]$. Egyéb hajlamosító tényező lehet még, ha a betegnek endometriosisa volt [8], vagy ha mediterrán lázban szenvedett [1]. A malignus peritonealis mesothelioma kialakulási valószínúségét az az- 
besztexpozíció egyértelmúen fokozza, ugyanakkor az azbesztexpozíció és a BMPM kialakulása között nem találtak összefüggést [6].

Egyes szerzők véleménye szerint a BMPM kialakulását és progresszióját a tumor nemi hormonokra való érzékenysége is befolyásolja. Az elméletet alátámasztja, hogy a betegség nagyobb gyakorisággal alakul ki reproduktív korú nőkben, mint férfiakban, emellett ritkán jelentkezik kétoldali adnexectomiát követően $[7,9]$. Néhány esetben a tumor reagált a tamoxifenre, illetve a gonadotropinfelszabadító hormonnal analóg agonistákra [10].

A BMPM a peritoneumon bárhol megjelenhet. A leggyakrabban a kismedencében, a petefészkeken, a vastagbélen, illetve a petevezetékeken jelenik meg az elváltozás. Eddig csupán néhány olyan eset került leírásra, amikor férfiaknál a tunica vaginalis területén, illetve nók esetében a Nuck-csatornában jelent meg a daganat $[3,7$, 10]. A cysta mérete 0,3 és $15 \mathrm{~cm}$ között mozoghat. Szerkezetét tekintve megjelenhet vékony falú egyrekeszes cystaként vagy szőlőfürtszerű többrekeszes cystosus elváltozásként. Az egyrekeszes cysták fala általában vékony és áttetsző, ezzel szemben a többrekeszes elváltozások fala jelentős mennyiségú kötőszövetes elemet tartalmazhat. A cysták tartalma általában savós folyadék [9, 10].

Néhány olyan eset is ismert, amikor a BMPM terhesség alatt vagy császármetszés során került felismerésre, a legtöbb esetben azonban emiatt a terhesség megszakítására nem volt szükség $[11,12]$.

A kórkép az akut appendicitis klinikai képét is utánozhatja, ilyenkor a laparoszkópos mútét során derül fény a jobb alhasi régióban elhelyezkedő cystosus elváltozásokra [13].

Ritka előfordulása és aspecifikus tünettana miatt a preoperatív diagnózis felállítása komoly kihívást jelent. Fizikális vizsgálat során csak a nagyobb méretű elváltozások tapinthatók. A képalkotó vizsgálatok általában nem képesek a pontos diagnózis felállítására [8].

A BMPM vékony falú cystosus elváltozás formájában kerülhet felismerésre hasi, illetve intravaginalis ultrahangvizsgálat során. A betegségre nem jellemző a mikrokalcifikáció jelenléte. A cystákban jelen lehetnek fehérjetörmelékek, illetve apró bevérzések is. Vastagabb falú cysták esetén elsősorban malignus elváltozásra kell gondolni. A BMPM bizonyos esetekben szorosan tapadhat a petefészekre, melynek struktúráját eltorzítja, de nem hatol be a szerv parenchymájába. Hasi CT-, illetve MRIvizsgálatok alkalmasabbak az elváltozás kimutatására, és pontosabb információt nyújtanak a betegség helyéről és kiterjedéséről is $[2,14]$. Lymphadenopathia, illetve ascites jelenléte esetén felmerül egyéb betegség, leginkább malignus elváltozás lehetősége. A szakirodalmi adatok alapján BMPM jelenléte esetén a tumormarkerértékek nem emelkednek meg. Amennyiben a vizsgálatok során felmerül a BMPM lehetősége, szövettani vizsgálat szükséges a pontos diagnózis felállításához. Szövettani diagnózis felállítására az FNAB alkalmatlan, ellenben igazol- ni lehet a betegséget a laparoszkópos exploráció során vett mintavétellel $[2,15,16]$. Sajnos nagyon ritkán merül fel már preoperatíve vagy akár a mútét alatt a BMPM lehetősége, ezért az esetek döntő többségében csak a végleges szövettani vizsgálat segítségével sikerül definitív diagnózishoz jutni.

A kismedencében, illetve a hasüregben elhelyezkedő cystosus terimék esetén mindig gondolnunk kell a malignus elváltozás lehetőségére is. Ki kell zárnunk a malignus peritonealis mesotheliomát, a peritonalis carcinosist, a cystadenocarcinomát vagy a pseudomyxoma peritoneit $[2,16]$.

Az általunk ismertetett két eset multicysticus elváltozásnak felelt meg. A cysták változó nagyságúak voltak, közöttük vékony sejtszegény kötőszövetes sövények helyezkedtek el. A cysták lumenében kevés halvány eosinophil, serosus jellegü anyag volt, míg a belfelszínt egyrétegú, típusos sejtekből felépülő mesothel bélelte, néhány ponton ún. bakancsszegszerü megjelenéssel. Fokálisan a mesothelsejtek proliferációja kiszélesedett lemezeket alkotott, papillaris struktúrák nélkül. Citológiai atípia, nucleolus vagy mitosis nem volt látható. A jellegzetes szöveti képre való tekintettel immunhisztokémiai vizsgálatok nem történtek. A szövettani vizsgálat BMPM-t/peritonealis inclusiós cystát igazolt.

A terminológiai kettősség etiopatológiai bizonytalanságra utal. Egyes esetek reaktív jellegúek, korábbi mútéti beavatkozással, endometriosissal állnak összefüggésben, és kedvező prognózisúak. Az esetek kisebb részében ugyanakkor a fenti állapotok hiányában kialakult elváltozás alapján néhány szerző neoplasticusnak tartja a BMPM-t. A progresszióra való hajlam a szövettani kép alapján nem határozható meg megbízhatóan.

Szövettanilag differenciáldiagnosztikai tumor cysticus formája, lymphangioma, cysticus endosalpingiosis, illetve malignus mesothelioma merülhet fel. A klinikai kép, a kórtörténet, valamint a citológiai atípia és a mitoticus aktivitás hiánya a malignus folyamat ellen szól. Az adenomatoid tumor cysticus formája legalább fokálisan tartalmaz klasszikus megjelenésű területeket, cysticus endosalpingiosisban tubaris típusú hámsejtek, csillószőrös és secretoros sejtek bélelik a cystákat, míg lymphangioma esetében a cysticus struktúrák falában simaizom- és lymphoid sejtek jelennek meg [16, 17].

A BMPM megfelelő kezelési stratégiája még nem teljesen tisztázott. Egyes vélemények alapján elégséges konzervatív terápiát folytatni [10], míg mások már a primer ellátás során agresszívebb terápiát javasolnak [2]. A kezelés megkezdése előtt javasolt szövettani diagnózishoz jutni, amelyre laparoszkópos exploráció során történt mintavétellel, illetve szövettani feldolgozás keretén belül van lehetőség [2].

Konzervatív kezelés során orális fogamzásgátlók szedését lehet alkalmazni, sikeresség esetén megakadályozva a daganat további növekedését [10]. Egy másik lehetőség a cysták aspirációja, illetve sclerotherapiája lehet, szá- 
molva a megszokottnál is magasabb recidíva kialakulásának veszélyével [8].

Mások véleménye alapján a primer ellátás minimum sebészi reszekció kell, hogy legyen. Javasolják a daganat en bloc eltávolítását, cytoreductiv sebészettel kiegészítve [8]. Mérettől és elhelyezkedéstől függően a BMPM laparoszkópos módon is biztonsággal eltávolítható [18]. Recidíva esetén mérlegelendő a totális peritonectomia elvégzése, amely egyértelmúen csökkenti a recidíva valószínűségét. Bár a hosszú távú eredmények jók, a kiterjesztett mútét a közvetlen posztoperatív szakban jelentősen magas morbiditással és mortalitással jár [2, 19].

Más szerzők véleménye alapján a BMPM kezelésében az elsőként választandó kezelési módszer a totális peritonectomia, illetve a HIPEC elvégzése. A HIPEC során a hasüreget $41-42{ }^{\circ} \mathrm{C}$-ra felmelegített kemoterápiás folyadékkal mossák át. A leggyakrabban alkalmazott kemoterápiás szerek a ciszplatin és a doxorubicin [1]. A beavatkozás időtartama $20-30$ perc, ezalatt a kemoterapeutikum közvetlenül tudja kifejteni hatását. Ilyenkor a szisztémás mellékhatások elhanyagolhatók, ugyanakkor a posztoperatív szövődmények valószínűsége $30 \%$ körüli $[4,8,19]$.

Mivel a BMPM alapvetően benignus viselkedésú daganat, mütétet követően onkológiai kezelésre nincs szükség. Az elváltozás a primer eltávolítástól kezdve akár évtizedekkel később is újra megjelenhet. A magas recidívaarány miatt szoros utánkövetés javasolt, emellett néhány olyan eset is leírásra került, amikor a daganat malignus transzformációt mutatott. Az elváltozás ritkasága, illetve az irányelvek hiánya miatt a betegek egy része nem részesül utánkövetésben, illetve esetenként a megfeleló kezelési módszerek alkalmazása is elmarad. Az utánkövetés során javasolt a rendszeres fizikális vizsgálat, illetve radiológiai képalkotó vizsgálatok elvégzése [3, 7, 17]. Egyes szerzők szerint a beavatkozást követően javasolt az első évben 3 havonta, majd a következő 5 évben évente elvégezni kontroll hasi-kismedencei CT-vizsgálatot [2].

Összességében elmondható, hogy a BMPM kezelésére fontos megfelelő, egyénre szabott terápiát alkalmazni, emellett a magas recidívahajlam, illetve a malignus átalakulás lehetősége miatt hosszú távon is ajánlott a beteg utánkövetése [19, 20].

Anyagi támogatás: A közlemény megírása, illetve a kapcsolódó kutatómunka anyagi támogatásban nem részesült.

Szerzői munkamegosztás: Gy. A.: Adatgyüjtés, a kézirat megírása. S. F., T. L. B.: A mütét elvégzése. Sz. H.: Szövettani vizsgálat. L. P.: A kézirat megírása és javítása. A cikk végleges változatát valamennyi szerző elolvasta és jóváhagyta.

Érdekeltségek: A szerzőknek nincsenek érdekeltségeik.

\section{Irodalom}

[1] Khurram MS, Shaikh H, Khan U, et al. Benign multicystic peritoneal mesothelioma: a rare condition in an uncommon gender. Case Rep Pathol. 2017; 2017: 2-3.

[2] Khuri S, Gilshtein H, Abboud W, et al. Benign cystic mesothelioma of the peritoneum: a rare case and review of the literature. Case Rep Oncol. 2012; 5: 667-670.

[3] Canbay E, Ishibashi H, Sako S, et al. Late recurrence of benign multicystic peritoneal mesothelioma complicated with an incisional hernia. Case Rep Surg. 2013; 2013: 903795.

[4] Elbouhaddouti H, Bouassria A, Mouaqit O, et al. Benign cystic mesothelioma of the peritoneum: a case report and literature review. World J Emerg Surg. 2013; 8: 43.

[5] Bray Madoué K, Boniface M, Annick Laure E, et al. Benign cystic peritoneal mesothelioma revealed by small bowel obstruction. Case Rep Radiol. 2016; 2016: 6728160

[6] Dzieniecka M, Kałużyński A. Benign multicystic peritoneal mesothelioma (BMPM) - case report and review of the literature. Pol J Pathol. 2011; 62: 122-124.

[7] Pitta X, Andreadis E, Ekonomou A, et al. Benign multicystic peritoneal mesothelioma: a case report. J Med Case Rep. 2010; 4: 385.

[8] Zhang CH, Yu JW, Luo M. Multicystic peritoneal mesothelioma: a short review. Curr Probl Cancer 2017; 41: 340-348.

[9] Sawh RN, Malpica A, Deavers MT, et al. Benign cystic mesothelioma of the peritoneum: a clinicopathologic study of 17 cases and immunohistochemical analysis of estrogen and progesterone receptor status. Hum Pathol. 2003; 34: 369-374

[10] Occhionorelli S, Tartarini D, Pascale G, et al. Benign multicystic mesothelioma of peritoneum complicating acute appendicitis in a man: a case report. J Med Case Rep. 2016; 10: 44.

[11] Snyder J, Carman R Jr, Aggon A, et al. Benign multicystic peritoneal mesothelioma: a rare case presenting as pneumoperitoneum and pneumotosis intestinalis. J Gastrointest Oncol. 2011; 2: $55-58$.

[12] Tamhankar VA. Multicystic benign mesothelioma complicating pregnancy. Case Rep Obstet Gynecol. 2015; 2015: 687183.

[13] González-Moreno S, Yan H, Alcorn KW, et al. Malignant transformation of 'benign' cystic mesothelioma of the peritoneum. J Surg Oncol. 2002; 79: 243-251.

[14] Veldhuis WB, Akin O, Goldman D, et al. Peritoneal inclusion cysts: clinical characteristics and imaging features. Eur Radiol. 2013; 23: 1167-1174.

[15] Rapisarda AM, Cianci A, Caruso S, et al. Benign multicystic mesothelioma and peritoneal inclusion cysts: are they the same clinical and histopathological entities? A systematic review to find an evidence-based management. Arch Gynecol Obstet. 2018; 297 : $1353-1375$.

[16] Cha KS, Choi YH, Lee YS, et al. Benign multicystic peritoneal mesothelioma treated with laparoendoscopic single site surgery: a case report and review of the literature. Obstet Gynecol Sci. 2018; 61: 170-174.

[17] Wang TB, Dai WG, Liu DW, et al. Diagnosis and treatment of benign multicystic peritoneal mesothelioma. World J Gastroenterol. 2013; 19: 6689-6692.

[18] Sizzi O, Rosetti A, Torcia F, et al. Laparoscopic treatment of benign multicystic mesothelioma. J Minim Invasive Gynecol. 2011; 18: 287

[19] Mehta S, Gelli M, Agarwal D, et al. Complications of cytoreductive surgery and HIPEC in the treatment of peritoneal metastases. Indian J Surg Oncol. 2016; 7: 225-229.

[20] Lee CE, Agrawal A. Remote recurrence of benign multicystic peritoneal mesothelioma. J Obstet Gynaecol Can. 2017; 39: $1042-1045$.

(György Alpár dr.,

Vecsés, Budai Nagy Antal u. 96/A, 2220 e-mail: gyorgy_alpar@yahoo.com) 